First publ. in: Nature 400 (1999), pp. 693-696

\section{Trigger factor and DnaK cooperate in folding of newly synthesized proteins}

\author{
Elke Deuerling, Agnes Schulze-Specking, \\ Toshifumi Tomoyasu, Axel Mogk \& Bernd Bukau
}

Institut für Biochemie und Molekularbiologie, Hermann-Herder-Strasse 7, 79104 D-Freiburg, Germany

The role of molecular chaperones in assisting the folding of newly synthesized proteins in the cytosol is poorly understood. In Escherichia coli, GroEL assists folding of only a minority of proteins $^{1}$ and the Hsp70 homologue DnaK is not essential for protein folding or cell viability at intermediate growth temperatures $^{2}$. The major protein associated with nascent polypeptides is ribosome-bound trigger factor $^{3,4}$, which displays chaperone and prolyl isomerase activities in vitro $^{3,5,6}$. Here we show that $\Delta$ tig::kan mutants lacking trigger factor have no defects in growth or protein folding. However, combined $\Delta$ tig::kan and $\Delta d n a K$ mutations cause synthetic lethality. Depletion of DnaK in the $\Delta t i g:: k a n$ mutant results in massive aggregation of cytosolic proteins. In $\Delta$ tig::kan cells, an increased amount of newly synthesized proteins associated transiently with DnaK. These findings show in vivo activity for a ribosome-associated chaperone, trigger factor, in general protein folding, and functional cooperation of this protein with a cytosolic Hsp70. Trigger factor and DnaK cooperate to promote proper folding of a variety of $E$. coli proteins, but neither is essential for folding and viability at intermediate growth temperatures.

Because trigger factor can associate with ribosomes and nascent polypeptide chains, it is a prime candidate for a chaperone that is dedicated to assist folding of newly synthesized proteins. To elucidate its in vivo role genetically, we replaced the complete coding sequence of the tig gene (encoding trigger factor) with a kanamycin cassette (Fig. 1a). The $\Delta$ tig::kan mutant lacking trigger factor was viable and showed no growth defects between 15 and $42{ }^{\circ} \mathrm{C}$ in rich (Fig. 1b) and minimal media (not shown). Furthermore, $\Delta$ tig::kan mutants showed no defects in protein folding at 30 and $37^{\circ} \mathrm{C}$, as judged by unaltered specific activities of a reporter enzyme (firefly luciferase) and solubility of cellular proteins. Trigger factor is thus not essential for viability and protein folding in E. coli.

We investigated whether other chaperones compensate for the missing activity of trigger factor in $\Delta$ tig::kan cells by determining the phenotypes resulting from combining the $\Delta$ tig::kan allele with additional chaperone-gene mutations. The $\Delta$ tig::kan allele could be transduced with normal efficiency into the chromosomes of $\Delta h t p G:: l a c Z$ (ref. 7), secB::Tn5 (ref. 8), $\Delta i b p A B:: k a n$ (unpublished results) and temperature-sensitive groEL mutants (L140, L673 and L44 $)^{9}$ without apparent alteration of the existing growth phenotypes. However, it could not be introduced into $\Delta d n a K 52$ mutant cells ${ }^{10}$, which lack DnaK and have low levels of the DnaJ cochaperone. This finding was further substantiated by co-transduction experiments in which a Tn10 selective marker (zba-3054::Tn10) placed close to the $\Delta$ tig::kan allele was transduced into $\Delta d n a K 52$ and $d n a K^{+}$cells. The co-transduction frequency of the $\Delta$ tig::kan allele was $83 \%$ in $d n a K^{+}$cells and $0 \%$ in $\Delta d n a K 52$ mutant cells. Combination of the $\Delta$ tig::kan and $\Delta d n a K 52$ mutations thus causes synthetic lethality.

To investigate the cause of the synthetic lethality, we constructed $\Delta$ tig::kan and tig $^{+}$strains in which expression of the chromosomal dnaK dnaJ operon is under the control of the IPTG-regulatable promoter $\mathrm{P}_{\mathrm{A} 1 / \mathrm{lacO}-1}\left(\mathrm{P}_{\mathrm{IPTG}} \text { dnaKJ, Fig. 1a }\right)^{11}$. On plates containing $1 \mathrm{mM}$ IPTG, the $\mathrm{P}_{\mathrm{IPTG}} d n a K J \Delta$ tig::kan and $\mathrm{P}_{\mathrm{IPTG}} d n a K J$ tig ${ }^{+}$strains formed colonies at all temperatures tested $\left(15,30,37\right.$ and $\left.42^{\circ} \mathrm{C}\right)$. On plates lacking IPTG, the $\mathrm{P}_{\mathrm{IPTG}}$ dnaKJ tig $^{+}$cells did not form colonies at 15 and $42^{\circ} \mathrm{C}$ (Fig. 1b), consistent with the cold-sensitive and heat-sensitive phenotype of $\Delta d n a K 52$ mutants $^{12}$. In the absence of IPTG, $\mathrm{P}_{\mathrm{IPTG}} d n a K J \Delta$ tig::kan cells did not form colonies at any temperature tested (Fig. 1b); growth of these mutants at 30 and $37^{\circ} \mathrm{C}$ was restored by expression of the tig gene from plasmids (not shown). The onset of synthetic lethality could also be monitored in liquid medium (Fig. 1c). After overnight growth in medium with IPTG, $\mathrm{P}_{\text {IPTG }}$ dnaKJ $\Delta$ tig::kan and $\mathrm{P}_{\text {IPTG }}$ dnaKJ tig ${ }^{+}$cells were diluted into medium lacking IPTG. DnaK and DnaJ levels decreased from about twice wild-type levels to undetectable amounts after $8 \mathrm{~h}$ growth without IPTG (time point 3, Fig. 1c). $\mathrm{P}_{\mathrm{IPTG}}$ dnaKJ $\Delta$ tig::kan cells depleted for DnaK and DnaJ started to show slower growth after $8 \mathrm{~h}$ (time point 3 ). At 8 and $10 \mathrm{~h}$ (time points 3 and 4 ), viability (determined as plating efficiency) decreased by 3 and 5 orders of magnitude, respectively, below the $\mathrm{P}_{\mathrm{IPTG}} d n a K J \Delta$ tig::kan control grown with IPTG.

To account for synthetic lethality, we first ruled out that it resulted from DnaK's regulatory role as a negative modulator of $\sigma^{32}$, the transcriptional activator of chaperone and protease genes of the heat-shock regulon ${ }^{13}$. Accordingly, overproduction of chaperones and proteases resulting from DnaK and DnaJ depletion may be poisonous for $\Delta$ tig::kan cells. We artificially induced the heat-shock response in $\Delta$ tig::kan cells using a plasmid expressing the $r p o H$ gene (encoding $\sigma^{32}$ ) under the control of an IPTG-inducible promoter ${ }^{14}$. IPTG-induced chaperone overproduction was at least as high as chaperone overproduction caused by DnaK and DnaJ depletion (monitored, for example, for GroEL, Fig. 1d) but did not affect the viability of $\Delta$ tig::kan cells at 30 and $37^{\circ} \mathrm{C}$ (Fig. 1d, lower panel).

To investigate whether synthetic lethality is caused by protein- 
folding defects, we first tested the in vivo folding efficiency of firefly luciferase. At $5 \mathrm{~h}$ of growth without IPTG (time point 2, Fig. 1c) at $30^{\circ} \mathrm{C}$, DnaK and DnaJ levels were about 6-times lower than wildtype levels. Growth, viability and protein synthesis were not yet affected (data not shown). At this time point, synthesis of plasmidencoded luciferase was induced for $30 \mathrm{~min}$. Luciferase activity was reduced by $60-70 \%$ in $\mathrm{P}_{\mathrm{IPTG}} d n a K J \Delta$ tig::kan cells as compared to $\mathrm{P}_{\text {IPTG }}$ dnaKJ tig ${ }^{+}$cells, although the amounts of luciferase present in both strains were similar (Fig. 2a). This decrease in specific activity was accompanied by increased luciferase aggregation (Fig. 2b).

We then tested the folding efficiency of $E$. coli bulk proteins. After $5 \mathrm{~h}$ of growth without IPTG (time point 2), cells were pulselabelled with ${ }^{35} \mathrm{~S}$-methionine for $15 \mathrm{~s}$ and analysed for protein aggregation. Aggregated proteins and some membrane proteins were recovered by centrifugation and separated by two-dimensional-gel electrophoresis, followed by staining of pre-existing proteins and autoradiographic detection of newly synthesized proteins (Fig. 3). There was a large increase in the number $(\sim 40$ proteins) and total amount (2.5-fold) of pelleted pre-existing proteins in $\mathrm{P}_{\mathrm{IPTG}} d n a K J \Delta$ tig::kan cells as compared to $\mathrm{P}_{\mathrm{IPTG}} d n a K J$ tig $^{+}$cells (Fig. 3a) and cells of both strains grown in IPTG (not shown). Most spots that increased in intensity correspond to cytosolic proteins and thus represent aggregated proteins (for example, MetE and RpoB showed 4- and 25-fold increased aggregation, respectively; Fig. 3a, right panel). The amounts of membrane proteins present in the pellet fraction remained similar in the two strains tested (for example, inner and outer membrane proteins AtpD and OmpA; Fig. 3a), indicating that protein-folding defects affected predominantly non-membrane proteins. The autoradiogram revealed quantitatively (2.5-fold overall increase) and qualitatively similar changes in the solubility of newly synthesized proteins (Fig. 3b). Exposure of the gel was extended to allow detection of minor spots, but this also increased background staining, including that by nascent polypeptide chains.

The extent to which proteins misfold in DnaK- and DnaJdepleted $\Delta$ tig::kan cells may be larger than detected, because proteases may degrade misfolded proteins and other chaperones may partially prevent aggregation. Furthermore, folding problems probably become more severe at later time points after IPTG withdrawal, conditions that were difficult to investigate because of general defects in, for example, protein synthesis.

To determine the functional relationship between DnaK and a

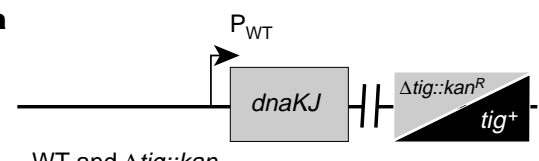

WT and $\Delta$ tig::kan

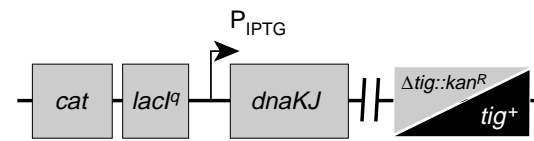

$\mathrm{P}_{\mathrm{IPTG}}$ dnaKJ tig ${ }^{+}$and $\mathrm{P}_{\mathrm{IPTG}}$ dnaKJ $\Delta$ tig::kan

$\boldsymbol{C}$
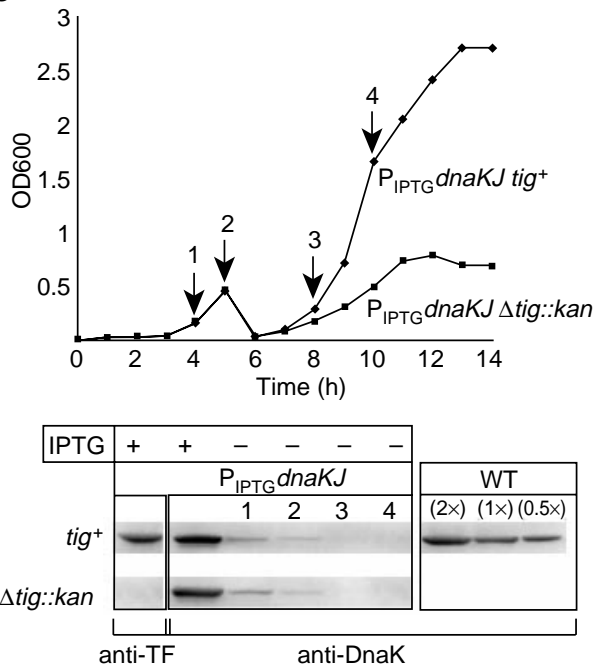
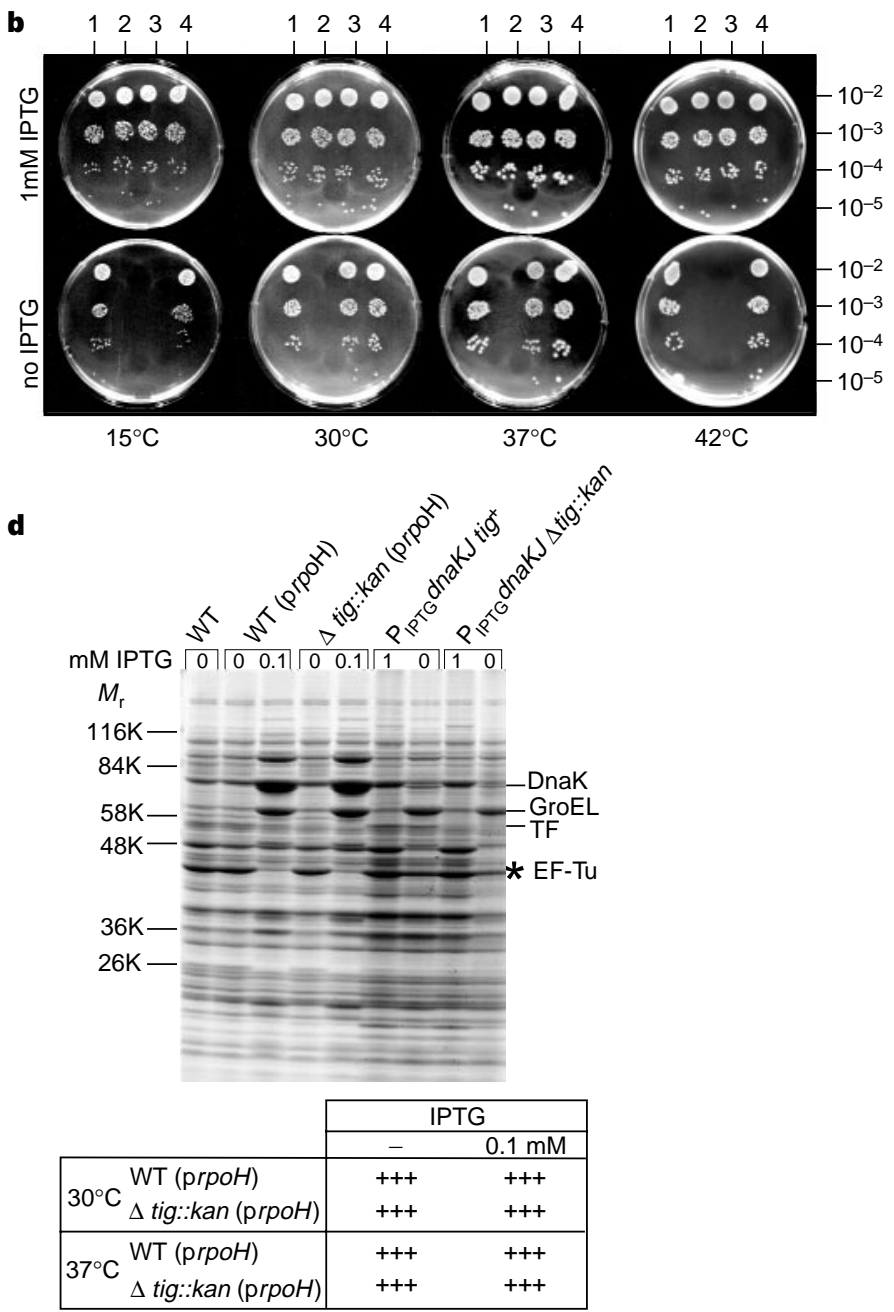

Figure 1 Synthetic lethality. a, Relevant genotypes of used strains. WT, wild type. b, Growth of wild-type (1), $\mathrm{P}_{\mathrm{PPTG}} d n a K J \Delta$ tig::kan (2), $\mathrm{P}_{\mathrm{IPTG}} d n a K J$ tig $^{+}$(3) and $\Delta$ tig::kan (4) cells on LB plates with or without IPTG at indicated temperatures for 24 or $96 \mathrm{~h}$ $\left(15^{\circ} \mathrm{C}\right) .10 \mu \mathrm{l}$ of diluted cultures were spotted. c, Growth of $\mathrm{P}_{\mathrm{IPTG}} d n a K J$ tig $^{+}$and $\mathrm{P}_{\mathrm{IPTG}}$ dnaKJ $\Delta$ tig::kan cells in LB liquid medium without IPTG at $37^{\circ} \mathrm{C}$. Top: at an $\mathrm{OD}_{600}$ of 0.6 , cells were diluted to maintain logarithmic growth. Arrows indicate time points of sample withdrawals. Similar growth behaviour was found for cells grown in $\mathrm{M} 9$ medium at $37^{\circ} \mathrm{C}$. Bottom: to detect DnaK and trigger factor levels during depletion, identical $\mathrm{OD}_{600}$ equivalents were harvested at time points 1 to 4 (upper panel) and immunoblot analysis was performed using specific antisera. As controls, different $\mathrm{OD}_{600}$ equivalents of wild-type cells were applied. d, Protein patterns of $\sigma^{32}$ and $d n a K$, dnaJ-regulatable tig $^{+}$and $\Delta$ tig::kan cells. Top: Coomassie-stained SDS-PAGE of total lysates (identical $\mathrm{OD}_{600}$ equivalents) of cultures grown in LB at $37^{\circ} \mathrm{C}$ with IPTG or depleted from IPTG for $5 \mathrm{~h}$. EF-Tu, for unknown reasons, is reduced in $\sigma^{32}$-overproducing cells. Bottom: growth of wildtype and $\Delta$ tig.:.kan cells with and without IPTG-induced $\sigma^{32}$ overproduction on LB agar. 


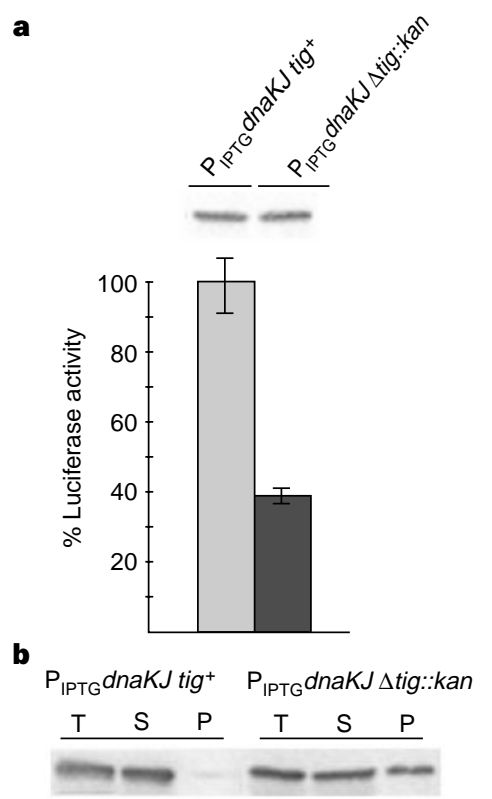

Figure 2 Specific activity and aggregation of firefly luciferase. a, In vivo activity and cellular levels of firefly luciferase in $\mathrm{P}_{\mathrm{IPTG}} d n a K J$ tig $^{+}$(light-grey bar) and $\mathrm{P}_{\mathrm{IPTG}} d n a K J \Delta$ tig::kan cells (dark-grey bar). DnaK- and DnaJ-depleted cells were induced for $30 \mathrm{~min}$ to produce luciferase and assayed for luciferase activity ${ }^{2}$ (set $100 \%$ for $\mathrm{P}_{\mathrm{IPTG}}$ dnaKJ tig ${ }^{+}$cells). Upper panel: identical $\mathrm{OD}_{600}$ culture equivalents of the cells were subjected to immunoblot analysis with luciferase-specific antiserum. b. Solubility of luciferase. Lysates of cells treated as for a were prepared, divided into soluble and insoluble fractions by centrifugation and analysed by immunoblotting with luciferase-specific antiserum. Total lysate $(T)$, supernatant (S) and aggregated material recovered in the pellet ( $\mathrm{P}$; double amount loaded). trigger factor, we tested whether, in the absence of trigger factor, DnaK shows altered association with newly synthesized proteins $\mathrm{tig}^{+}$ and $\Delta$ tig::kan cells were labelled for $15 \mathrm{~s}$ with ${ }^{35} \mathrm{~S}$-methionine and DnaK-bound substrates were rapidly recovered by co-immunoprecipitation with DnaK-specific antisera (Fig. 4a). About $2-4 \%$ of total labelled protein co-immunoprecipitated with DnaK from $\mathrm{tig}^{+}$ cells, whereas 2-3-fold more labelled material was initially coimmunoprecipitated from $\Delta$ tig::kan cells (Fig. 4a, lower panel). The labelled material consisted of various proteins appearing as a smear (Fig. 4a), probably because nascent polypeptides were among these substrates. Chasing with non-radioactive methionine for 1-10 min before co-immunoprecipitation converted the smear to distinct bands, some of which associated with DnaK to similar extents in tig $^{+}$and $\Delta$ tig cells (Fig. 4a). Some nascent chains showed a rapid flux through DnaK $(<1 \mathrm{~min}$ half-life), the extent, or perhaps the kinetics, of their association with DnaK being affected by trigger factor. Other proteins showed prolonged interaction with DnaK ( $>10 \mathrm{~min}$ half life), to an extent that is apparently not affected by trigger factor. The mechanistic basis for these protein classes remains unclear. Taking into account the efficiency of coimmunoprecipitation and the amount of recovered labelled protein, we estimate that $9-18 \%$ and $26-39 \%$ of newly synthesized proteins interact transiently with DnaK in wild-type and $\Delta$ tig::kan cells, respectively.

We also found that, in $\Delta$ tig::kan cells, a slightly increased amount (1.3-fold) of newly synthesized protein associates with GroEL (Fig. 4b). The most notable difference between the DnaK and GroEL substrates is an upper size limitation for GroEL substrates (relative molecular mass $\left(M_{\mathrm{r}}\right)$ of $\sim 65 \mathrm{~K}$ ). This size exclusion by GroEL of large proteins, which are particularly prone to aggregation in $\Delta$ tig::kan mutants depleted for DnaK and DnaJ, explains the importance of the DnaK chaperone system for protein folding in $\Delta$ tig::kan cells.
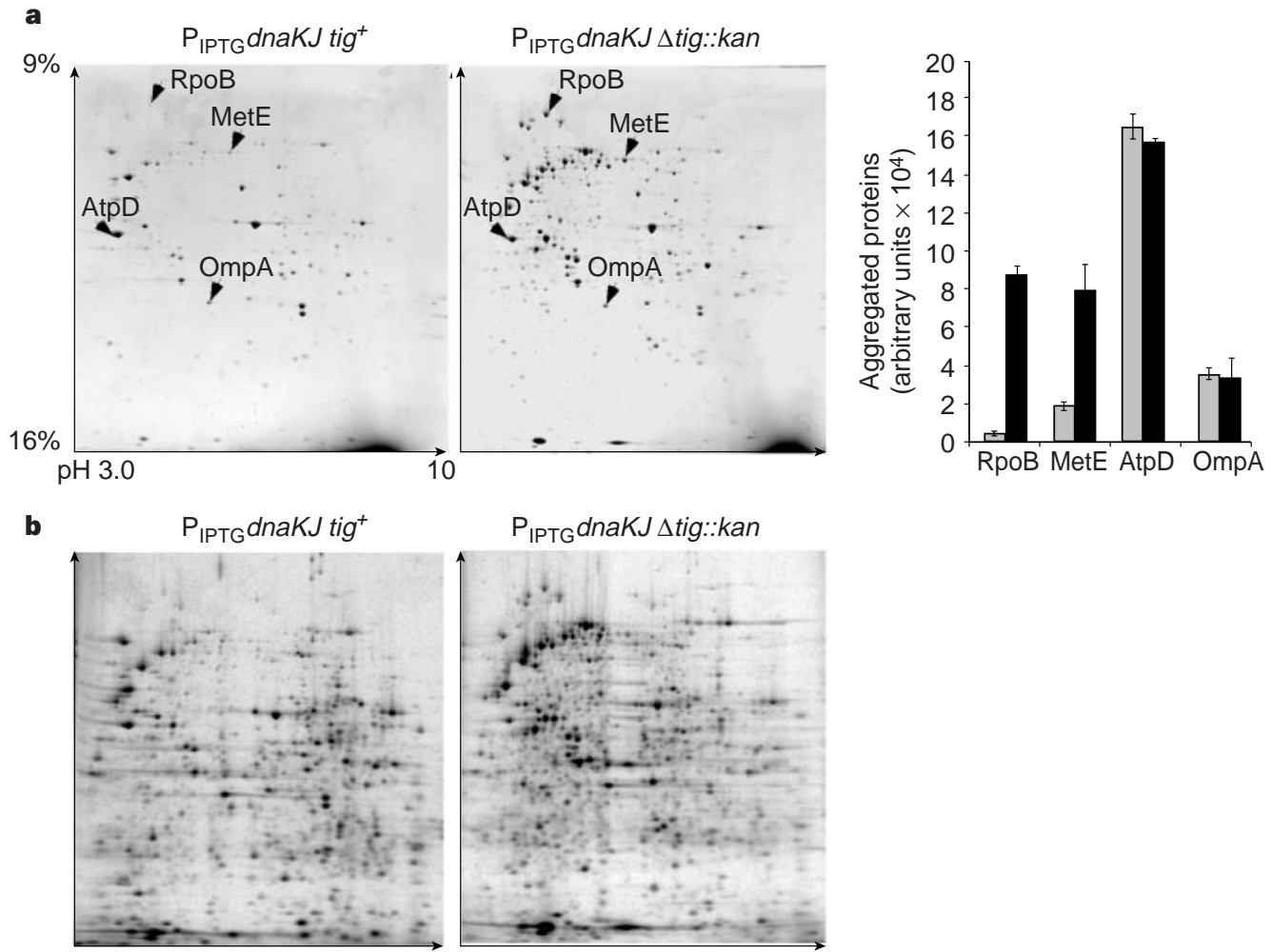

$\mathrm{P}_{\mathrm{IPTG}}$ dnaKJ $\Delta$ tig::kan

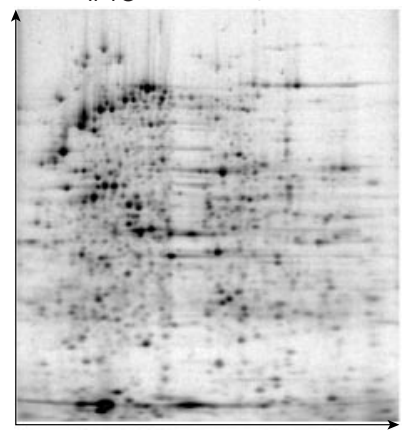

Figure 3 Aggregation of pre-existing and newly synthesized E. coli proteins. a, Coomassie-blue-stained gels of the pellet fractions of $\mathrm{P}_{\mathrm{IPTG}} d n a K J$ tig $^{+}$and PIPTGdnaKJ $\Delta$ tig::kan cells grown for $5 \mathrm{~h}$ in the absence of IPTG. Arrows indicate cytosolic (MetE, RpoB) and membrane (AtpD, OmpA) proteins identified by mass spectrometry. Right: spot quantification of the Coomassie-stained gels. $\mathrm{P}_{\mathrm{PTG}^{-}}$ dnaKJ tig ${ }^{+}$cells, light-grey bars; $\mathrm{P}_{\mathrm{IPTG}}$ dnaKJ tig::kan cells, dark-grey bars. Quantification was performed using ImageMaster 2D program (Amersham/ Pharmacia). b. Autoradiography of the Coomassie-stained gels shown in a. 
Our findings indicate cooperative functions for trigger factor and DnaK in folding of newly synthesized proteins, although neither function is essential for folding. Trigger factor probably acts cotranslationally, as it associates with ribosomes and nascent polypeptide chains ${ }^{3,15}$. DnaK associates co- and/or post-translationally with a subset of newly synthesized proteins even in the presence of trigger factor, indicating that it regularly participates in protein folding even in wild-type cells. The nature of the functional cooperation between trigger factor and DnaK remains unclear.

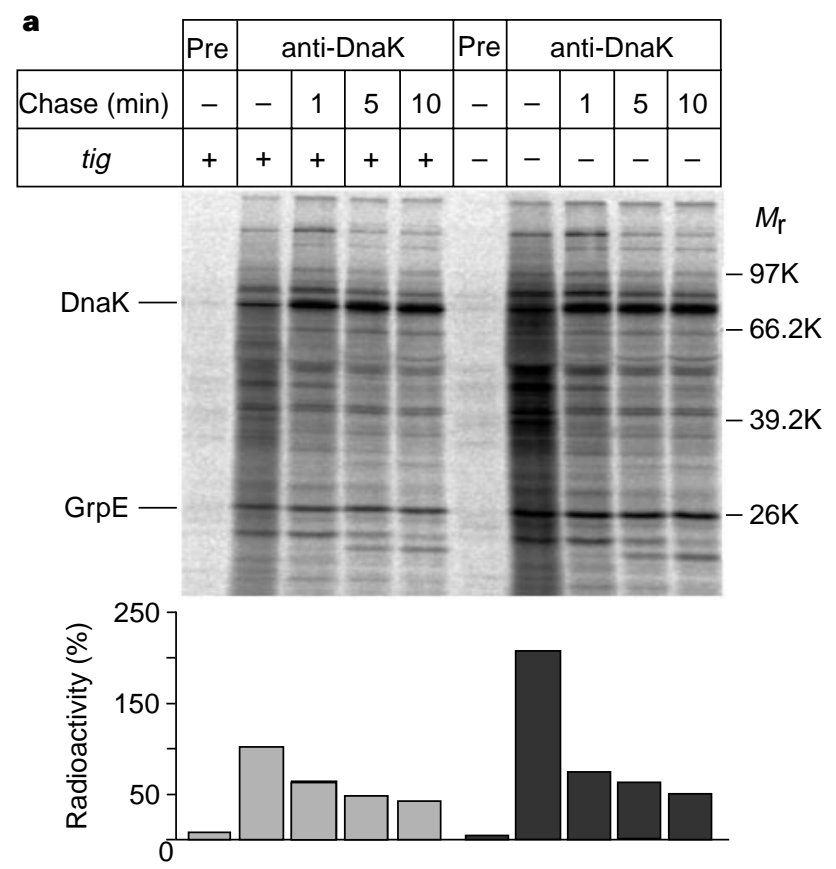

\begin{tabular}{l}
\cline { 2 - 9 } \multicolumn{1}{c|}{} \\
\begin{tabular}{|c|c|c|c|c|c|c|c|c|}
\hline Chase (min) & - & 1 & 5 & 10 & - & 1 & 5 & 10 \\
\hline tig & + & + & + & + & - & - & - & - \\
\hline
\end{tabular}
\end{tabular}
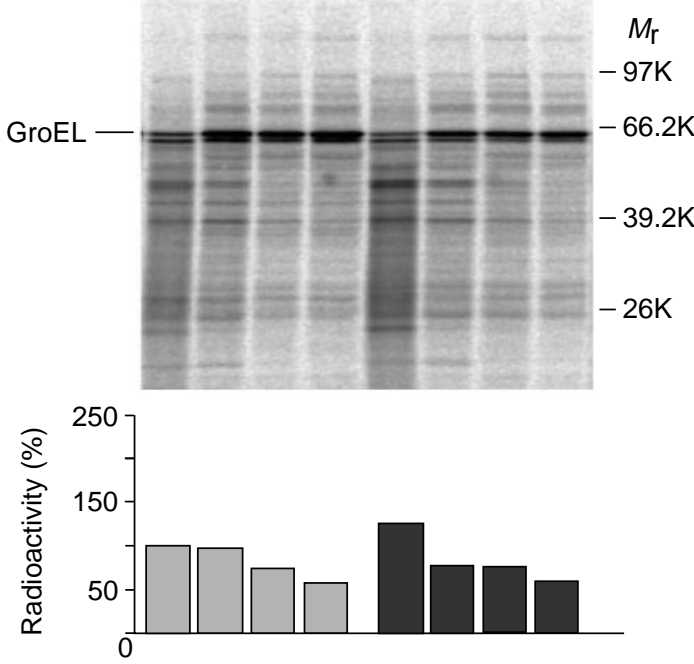

Figure 4 Association of DnaK with nascent polypeptide chains. a, Coimmunoprecipitation with DnaK-specific antisera. The lower panel shows quantification of radioactivity of the immunoprecipitated material above; tig $^{+}$, light-grey bars; $\Delta$ tig::kan, dark-grey bars. Radioactivity immunoprecipitated in the tig $^{+}$Iysate after $15 \mathrm{~s}$ pulse is set $100 \%$. b, Co-immunoprecipitation with GroELspecific antibodies. The lower panel shows quantification of radioactivity of the immunoprecipitated material. Radioactivity immunoprecipitated in the $\mathrm{tig}^{+}$lysate after 15 s pulse is set $100 \%$.

\section{Methods}

Growth of $\mathbf{P}_{\mathrm{IPTG}}$ dnaKJ cells. The strains used for depletion experiments are in the C600 background. Cells were grown overnight with $1 \mathrm{mM}$ IPTG (isopropyl- $\beta$-D-thiogalactoside), then washed three times in saline to remove IPTG, inoculated in fresh medium to an absorbance at $600 \mathrm{~nm}\left(\mathrm{OD}_{600}\right)$ of $0.015-0.03$ and grown for analyses without IPTG at $37^{\circ} \mathrm{C}$ for $\sim 5 \mathrm{~h}$ to $\mathrm{OD}_{600}=0.6-0.8$.

Luciferase activity. Cultures of $\mathrm{P}_{\mathrm{IPTG}} d n a K J$ tig ${ }^{+}$and $\Delta$ tig::kan cells containing plasmid pBB516 (ref. 11) were grown overnight at $30^{\circ} \mathrm{C}$ in LB medium with ampicillin $\left(100 \mu \mathrm{g} \mathrm{ml}^{-1}\right)$ containing $1 \mathrm{mM}$ IPTG, washed three times in saline $(0.8 \% \mathrm{NaCl})$ and inoculated in LB medium lacking IPTG to an $\mathrm{OD}_{600}$ of 0.030 . At mid-log phase, luciferase production was induced by the addition of $0.4 \%$ arabinose and in vivo activity was determined as described ${ }^{2}$.

Isolation of insoluble proteins. Cultures were grown at $37^{\circ} \mathrm{C}$ in $\mathrm{M} 9$ medium containing $0.2 \%$ glucose and all $\mathrm{L}$-amino acids except methionine to an $\mathrm{OD}_{600}$ of 0.6. Cells were pulsed with ${ }^{35} \mathrm{~S}$-methionine $\left(15 \mu \mathrm{Ci} \mathrm{ml}^{-1}\right.$ final concentration) for $15 \mathrm{~s}$, rapidly chilled on ice, lysed as described ${ }^{2}$ and the protein content was determined (Bradford assay, Biorad). We subjected $2.4 \mathrm{mg}$ protein of each lysate to a two-step centrifugation protocol where the first low-speed centrifugation removes most membrane proteins ${ }^{2}$. 2D-gel electrophoresis of pellet fractions was performed according to the distributor (Amersham/Pharmacia). Experiments were reproduced at least three times.

Co-immunoprecipitation. Ten-millilitre aliquots of cells grown in M9 medium at $37^{\circ} \mathrm{C}$ to mid-log phase were pulsed for $15 \mathrm{~s}$ with ${ }^{35} \mathrm{~S}$-methionine ( $15 \mu \mathrm{Ci} \mathrm{ml} l^{-1}$; Amersham) and chased by addition of unlabelled methionine $\left(160 \mu \mathrm{g} \mathrm{ml}^{-1}\right)$ when indicated. Cells were immediately transferred to $10 \mathrm{ml}$ of frozen crushed solution $(0.8 \% \mathrm{NaCl}, 10 \mathrm{mM}$ EDTA; $\mathrm{pH} 8.0)$, incubated for $5 \mathrm{~min}$ and then pelleted by low-speed centrifugation. Lysates were prepared as described $^{2}$, except that lysis buffer contained $100 \mathrm{mM}$ EDTA to prevent ATPdependent dissociation of DnaK-bound substrates, and that lysates were subjected to additional centrifugation for $5 \mathrm{~min}$ at $13,000 \mathrm{~g}$ to remove insoluble material before immunoprecipitation. Eighty microlitres of lysate $\left(2 \mathrm{mg} \mathrm{ml}^{-1}\right)$ was incubated with $80 \mu \mathrm{l}$ protein A-Sepharose beads in PBS, $4 \mu \mathrm{l}$ of appropriate antibodies and $1 \mathrm{ml}$ of RIPA-buffer $(50 \mathrm{mM}$ Tris/ $\mathrm{HCl}, 10 \mathrm{mM}$ EDTA, $150 \mathrm{mM} \mathrm{NaCl}, 0.5 \% \mathrm{NP}-40, \mathrm{pH} 7.5$ ) for $45 \mathrm{~min}$ at $8{ }^{\circ} \mathrm{C}$. Beads were washed 3 times with RIPA-buffer, once with PBS/ $5 \mathrm{mM}$ EDTA and finally boiled in $80 \mu \mathrm{l}$ SDS-sample buffer. Incorporation of ${ }^{35} \mathrm{~S}$-methionine in TCA-precipitated lysates was determined to correct for differences in the labelling of the lysates.

Received 6 May; accepted 29 June 1999.

1. Ewalt, K. L., Hendrick, J. P., Houry, W. A. \& Hartl, F. U. In vivo observation of polypeptide flux through the bacterial chaperonin system. Cell 90, 491-500 (1997).

2. Hesterkamp, T. \& Bukau, B. Role of the DnaK and HscA homologs of Hsp70 chaperones in protein folding in E. coli. EMBO J. 17, 4818-4828 (1998).

3. Hesterkamp, T., Hauser, S., Lütcke, H. \& Bukau, B. Escherichia coli trigger factor is a prolyl isomerase that associates with nascent polypeptide chains. Proc. Natl Acad. Sci. USA 93, 4437-4441 (1996).

4. Valent, Q. A. et al. Early events in preprotein recognition in E. coli: interaction of SRP and trigger factor with nascent polypeptides. EMBO J. 14, 5494-5505 (1995).

5. Scholz, C., Stoller, G., Zarnt, T., Fischer, G. \& Schmid, F. X. Cooperation of enzymatic and chaperone functions of trigger factor in the catalysis of protein folding. EMBO J. 16, 54-58 (1997).

6. Stoller, G. et al. A ribosome-associated peptidyl-prolyl cis/trans isomerase identified as the trigger factor. EMBO J. 14, 4939-4948 (1995).

7. Bardwell, J. C. A. \& Craig, E. A. Ancient heat shock gene is dispensable. J. Bacteriol. 170, 2977-2983 (1988).

8. Kumamoto, C. A. \& Beckwith, J. Mutations in a new gene, secB, cause defective protein localization in Escherichia coli. J. Bacteriol. 154, 253-260 (1983).

9. Zeilstra-Ryalls, J., Fayet, O., Baird, L. \& Georgopoulos, C. Sequence analysis and phenotypic characterization of groEL mutations that block $\lambda$ and T4 bacteriophage growth. J. Bacteriol. 175, $1134-1143$ (1993)

10. Paek, K. H. \& Walker, G. C. Escherichia coli dnaK null mutants are inviable at high temperature. J. Bact. 169, 283-290 (1987).

11. Tomoyasu, T., Ogura, T., Tatsuta, T. \& Bukau, B. Levels of DnaK and DnaJ provide tight control of heat shock gene expression and protein repair in E. coli. Mol. Microbiol. 30, 567-581 (1998).

12. Bukau, B. \& Walker, G. C. Cellular defects caused by deletion of the Escherichia coli dnaK gene indicates roles for heat shock protein in normal metabolism. J. Bacteriol. 171, 2337-2346 (1989).

13. Gross, C. A. in Escherichia coli and Salmonella (ed. Neidhardt, F. C.) 1382-1399 (ASM, Washington, 19996).

14. Gamer, J. et al. A cycle of binding and release of the DnaK, DnaJ and GrpE chaperones regulates activity of the E. coli heat shock transcription factor $\sigma^{32}$. EMBO J. 15, 607-617 (1996).

15. Valent, Q. A. et al. Nascent membrane and presecretory proteins synthesized in Escherichia coli associate with signal recognition particle and trigger factor. Mol. Microbiol. 25, 53-64 (1997).

Acknowledgements. We thank members of the Bukau lab, T. Hesterkamp, M. Müller and H.-G. Koch for comments on the manuscript and discussions. This work was supported by grants of the DFG and the Fonds der Chemie to B.B.

Correspondence and requests for materials should be addressed to B.B. (e-mail: bukau@sun2.ruf.unifreiburg.de). 